\title{
MOSCOW'S GREAT POWER DILEMMAS: THE ROLE OF ASIATIC RUSSIA IN RUSSIA-CHINA RELATIONS
}

\author{
Rafael Contreras-Luna* \\ Faculty of History and International Relations, Samara National Research \\ University, 34, Moskovskoye shosse, 443086, Samara, Russia \\ E-mail: rafaelc_luna@yahoo.com.mx
}

Published online: 15 July 2019

To cite this article: Contreras-Luna, R. 2019. Moscow's great power dilemmas: The role of Asiatic Russia in Russia-China relations. International Journal of Asia Pacific Studies 15 (2): 1-29, https://doi.org/10.21315/ijaps2019.15.2.1

To link to this article: https://doi.org/10.21315/ijaps2019.15.2.1

\begin{abstract}
Russia is one of the few countries to have a noun "velikoderzhavnost"greatpowerness - to define its status and position in the world. This "greatpowerness" is a central element of Russia's national identity and exerts huge influence in the country's foreign policy making. Similarly, Asiatic Russia is a prime component defining and promoting Russia's national identity and its quest for great power status as it conceives of itself as a great power straddling Europe and Asia. This paper looks at the way in which Asiatic Russia is conceptualised under Russia's great power's narrative. By the same token, it looks into specific issues of significance for Asiatic Russia, such as migration, demographics and economic development, and the way they have been both politicised and securitised. In this sense, the rise of China presents a major dilemma for Russia: on the one hand, Russia's actual engagement with China substantiates its identity as a global power; on the other hand, at a regional level China embodies a potential menace to Russia's greatpowerness. This article analyses relations between Russia and China, and attempts to describe the nexus between cooperation and the country's claims to great power. It is argued that Russo-Chinese regional interactions are the barometer of the overall RussiaChina relations. This paper attempts to connect three aspects-national identity, geographical settings and external strategy, to determine the place of Asiatic Russia in Russia's contemporary relations with China in the context of Russia's great power identity.
\end{abstract}

Keywords: Russia, great power, Asiatic Russia, Russia-China, national identity 


\section{INTRODUCTION}

Russia's self-perception of being a great power-velikoderzhavnost-defines its status and position in the world. This "greatpowerness" is a central element of Russia's national identity and one of the main drivers of Russia's foreign policy. Hanna Smith (2016) argues that greatpowerness is a uniting factor both within the Russian leadership and most of the population and between both groups. This article argues that one of the most important long-term factors influencing Russia's national identity was its expansion into Northern Asia with the conquest of the immense land that was called "Siberia." Siberia-Asiatic Russia - is a prime component contributing to national identity as Russia conceives of itself as a great power straddling Europe and Asia.

Russian foreign policy is often seen in International Relations through the lens of realism as it is framed within the framework of great powers' politics. Russia conceives itself as one of the great powers. The Russian leadership takes the realistic perspective that a great power is a nation that has great material power and the ability to project it. "Realism assumes that great powers value highly the components of sovereignty: freedom of international actions including conducting war, exclusive authority over domestic affairs and recognition as a legitimate international actor" (Ziegler 2012: 402). Nevertheless, it would be inaccurate to analyse Russia's foreign policy only through the prism of geopolitics or realism excluding a constructivist approach. As Anne Clunan (2014) argues, Russia's national interests and foreign policy cannot be defined on the basis of conventional cost-benefit assessments. Therefore, this article attempts to connect three aspectsnational identity, geographical settings and external strategy, to determine the place of Asiatic Russia in Russia's contemporary relations with China in the context of Russia's great power identity.

The evidence for this article was drawn primarily from the following categories of sources: book chapters, governmental documents, academic articles, news resources, Russian think tank's publications and personal interviews conducted in China (2013), Moscow (2015) and Saint Petersburg (2016) with academics. The article is divided into three broad sections: firstly, it briefly engages with literature on great power identity in the Russian context. By the same token, it analyses Russia's self-conceptualisation as a great power as a central element of Russian national identity and as one of the main drivers of Russia's foreign policy. Secondly, this paper looks at the way in which Asiatic Russia is conceptualised under Russia's great power's narrative. It looks into specific issues of significance for Siberia, and for the Russian Far East (RFE) in particular, such as migration, demographics and economic 
development, and the way they have been both politicised and securitised. The ongoing preoccupation with sovereignty and territory plays an important role in both internal and external affairs of Asiatic Russia. Thirdly, there follows an analysis of relations between Russia and China, and the place of Asiatic Russia within the overall bilateral relationship. It attempts to describe the nexus between cooperation and the country's reassertion of great power status. This section describes the political determinants of the bilateral ties and then analyses bilateral relations at a regional level, focusing the discussion on Russia's problems with security and development, and the implications of China's involvement in the context of Russia's great power identity.

In addition, the topic of this article seems to gain more relevance as Russia's confrontation with the West over the Ukraine and Syria evolves. Under Putin's presidency, the necessity of maintaining Russia's great power status and the necessity of maintaining good relations with the West were established and some progress was made. In the last years, however, Russia began to reassess its relations with the West. Consequently, it seems that Russia has to shift toward closer relations with Asian countries, particularly China, and Asiatic Russia importance rises once again as a factor in this endeavour.

\section{NATIONAL IDENTITY: GREATPOWERNESS}

National identity is a construct of the state created for the purpose of legitimating itself as distinct (Campbell 1998). A nation is not a homogeneous entity, however. Within a nation there are different groups and schools of thought which respond differently to international and local conditions and experiences and try to connect foreign policy and national identity (Clunan 2009; Tsygankov 2010). Each group has its own conception of national identity and the relationship of the nation with the international order. Within Russia, these groups have debated the place of Russia in the world by linking culture, history and beliefs with current affairs in the international arena.

There are different ways of breaking down the Russian political elites into different groups (Billington 2004; Bogaturov and Shakleyina 2004; Laruelle 2008; Light 2003; Lukin 2003; Neumann 1996; Rangsimaporn 2006; Sergunin 2004, 2016; Tsygankov 2010), but there are three which arguably represent the main Russian schools of thought on international affairs: "Westernism," "NeoEurasianism" and "Pragmatic Eurasianism." Each of these highlights different categories to explain the identity of Russia as a nation and consequently the type of foreign policy it should pursue. 
Immediately before and after the collapse of the Union of Soviet Socialist Republics (USSR), Westernism became the dominant force in the Russian national identity debate. Nevertheless, the political and economic elites in the 1990s did not take into account Russia's historical self-conception as a great power and therefore its national identity project ultimately failed (Clunan 2014). After polarisation and ungovernability in the 1990s, a "consensus" within the majority of the elite about Russian foreign policy prevailed and Pragmatic Eurasianism formed the new dominant national identity (Light 2003). This consensus could be described as the general agreement that Russia cannot be but a great power; it should be a strong and independent state in order to maintain order and stability (derzhava). This dominant force viewed the post-Cold War world as a multipolar one and urged the country to consolidate its position as a relatively independent power centre straddling the West and Asia. Accordingly, the majority of the Russian elites and most of the population have converged on the idea that Russia has to be a great power. Similarly, for the majority of Russian scholars Russia has to be counted in the list of great powers (Karaganov 2010; Lukyanov 2013; Tsygankov 2009). Indeed, President Putin has stated that Russia as a nation can only exist as a great power (Tsygankov 2005). Being a great power has been institutionalised as "it is the ultimate domestic requirement for any Russian leader" (Leichtova 2014: 14).

What is it to be a great power? It is often assumed there is a handful of countries called great powers whose influence in world affairs is much greater than that of the rest of the countries combined. Listing the countries that are meant to be great powers could be problematic, however, as the list seems to be intuitive in most cases. Kenneth Waltz (1979: 131) agrees with such intuitive lists: "Historically, despite the difficulties, one finds general agreement about who the great powers of a period are, with occasional doubt about the marginal cases." What are the criteria used to determine whether a country is a great power or not? There is no straightforward answer to this question.

Traditionally in International Relations, great power status is related to material capabilities: military strength, territory, resources, population, economic capabilities and strategic location. Nowadays, in addition to these hard power elements, soft power elements such as culture, country's attractiveness, technology and forms of government play an important role in claiming great power status. It is not an easy task to define what a great power is as there is not complete agreement on the definition of a great power or the parameters of greatpowerness (Smith 2016). Parameters of greatpowerness start to differ when it comes to forms of soft power. 
Until the seventeenth century, Russia had a marginal role in European politics and it would be difficult to consider it as a great power of the time by any criteria. As Iver Neumann notes (2008), it is generally agreed that the Great Northern War between Sweden and Russia embodies the accession of Russia as a great power along with other European powers such as France, Austria, Great Britain and the Netherlands. Similarly, the war signified the fall of Sweden as a great power. It can be said that from the reign of Peter I onwards, Russia had to be a great power but it became a different kind of great power at different points in history: Russian Empire and Soviet Union were different attempts to fulfil the criteria.

The Russian leadership established in the 1990s a narrative on Russia as a global power in a multipolar world, an attempt to regain its great power status by counterbalancing the United States unipolar order established after the collapse of the Soviet Union. Primakov was the main advocate of multipolarity during the Yeltsin era (Rangsimaporn 2009), and several times stressed "Russia's greatness" and Russia's status as a great power, but at that time, the arguments seemed unconvincing: Russia was a weak state undergoing a severe crisis.

The aim of achieving the status of a great power was more clearly defined under Putin's government, and he began to pursue this end more pragmatically. Putin's purpose was not to restore the Soviet as a superpower, but to make Russia a "normal great power." He has several times highlighted that Russia "is and will remain a great power" (Rangsimaporn 2009). For Putin, Russia has developed the capabilities of a great power in order to secure its borders. In fact, being a great power is a prerequisite for the existence of Russia as a nation: "The sanctification of Russia's great power status and the declared preference for a multipolar world order based on sovereignty and non-interference in states' internal affairs has been a constant" (Cadier and Light 2015: 23).

But what does it mean to Russia, to be a global power in a multipolar world? Firstly, Russia sees itself as an indispensable nation. It does not claim to be an exceptional nation, as the United States does, and indeed Putin has several times criticised United States exceptionalism. Russia's indispensability means that as a great power, "Russia once and for all wants to reserve a seat at the table where the future of the world is decided" (Lukyanov 2013). Secondly, it is essential for Russia to have a manoeuvrable foreign policy and the possibility of retaining the status of an independent strategic centre of power, thus avoiding entering the zone of attraction of some other strong centre. According to Sergei Lavrov (2012), Russia's Foreign Minister, 
"The independence of Russia's foreign policy is our achievement, gained over the preceding centuries of historical development and through the experience of the last 20 years. Russia cannot simply exist as a subordinate country of a world leader."

The conflict in the Ukraine from 2014 onwards, and the merger of Crimea with Russia, have pushed Russia in direct confrontation with the West. At the same time, this has created a large consensus among the elites and the population: the "post Crimea consensus" (Morozov 2015). According to this, the population accept economic hardships in return for the country's great power status. As noted by Trenin (2015: 42): "No recent issue has brought Russia's domestic and foreign policies as intimately together as Crimea and Ukraine."

For the Russian leadership and leading scholars, the main elements of what makes a country a great power are, especially, hard power elements (Leshchenko 2010; Shakleyina 2012). The Russian leadership follows a more realist approach in which great powers are countries that have material power and the ability to project it (Ziegler 2012). In this sense, Russia would have most of the attributes which traditionally have characterised great powers: military strength, territory, leadership in space, and natural resources. But in terms of economy and population, Russia has little likelihood of fulfilling the criteria. Russia's great power identity greatly differs from the understanding in the West of what is to be a great power, especially when it comes to soft power elements as Russia's understanding of soft power greatly differs from that of the West (Kiseleva 2015; Lukyanov 2015; Sergunin 2016).

Under Putin's administration, Russia includes traditional forms of hard power to claim great power status but it also includes soft power elements such as culture, science, education and diplomacy (Smith 2016). Russia has a serious image problem in western countries, especially after the conflict in Ukraine and Syria, therefore, it strives to better its image through soft power elements. Nevertheless, when it cannot, it appeals to its great power status and opposes its "own soft power" to that in the West. "Russia effectively reverses the logic of soft power, it lays claim to soft power automatically, as a consequence of its ostensibly obvious great powerhood" (Kiseleva 2015: 322). Russia's soft power is often framed in geopolitical terms. In this sense, Nye (2013) argues that Russia does not get what soft power is and therefore its efforts to increase its soft power will unlikely bring any meaningful results.

Nye is particularly critical on Russia and China in terms of how they interpret the concept of soft-power. According to Nye, the three main aspects of soft power are: attractiveness of diplomacy, attractiveness of political 
system, and attractiveness of culture. He does not include other elements such as economic factors. China and Russia have tried, however, to broaden this concept. In the words of Saint Petersburg scholar Alexander Sergunin: "for China and Russia, soft power is everything that is not hard power, that is, military power. Everything else is soft power. What it is not military is soft" (pers. comm. 16 September 2016). On the contrary, for Nye, most of the sources of soft power come from society, from the civil society, whereas in Russia they come from the state as Russian civil society is still in an "embryo stage" (pers. comm. 16 September 2016).

The issue is that Russia's soft power is not only "too soft" but it does not coincide with Western parameters. Russia's soft power is often framed in geopolitical terms. Consequently, in the West it is often questioned whether Russia is a great power or not. Historically, Russia has had problems being recognised as a great power by the European powers. Kiseleva (2015), Neumann $(2008,2015)$ and Ziegler (2012) argue that this lack of recognition is to a great extent due to a difference in governance. In his work, I Remember when Russia was a Great Power, Neumann (2015) argues that due to its weak social and economic power base, the Russian state is weak and has to shout to get things done at home and abroad. In this sense, the author asks: Why is Russia shouting about being a great power? He then says that when someone shouts about their status, this means that that status is insecure, as those who are secure in their status do not have to shout about it (Neumann 2015). It is beyond the scope of this article to discuss whether Russia can be considered a great power or not, however. By the same token, the aim of this work is not to analyse the reasons why Russia is not fully recognised by the West as a great power but to examine Russia's self-conceptualisation as a great power and its consequences in foreign policy.

The Russian leadership and elites have underlined Russia's "great" past to create a consensus in Russia's historical status as great power and "[...] to rebuild Russia's identity and national esteem on the basis of its historical great power status and Russia's integration on that basis into the international order" (Clunan 2014: 289). In this sense, Putin's presidency attempts to restate this "natural status" for Russia. As per Danilova (2017), "The political trend in recent years has been the confirmation of the general Russian idea and the construction of modern national identity on the basis of greatpowerness." This is, Russia's national identity is based not only on new realities, but also on historical ones that are considered natural for the country; "Among them is the idea of a strong state with a powerful army, the idea of the revival of Russia as a great power, and its conquest of a worthy place in the modern world" (Gadzhiev 2009). 
Russia as a great power is a central idea of national identity within both the elites and the population. The self-conceptualisation of being a great power has an important role in Russia's domestic policies and external relations. As per Smith (2016: 128), "greatpowerness is a concept that Russians have used to describe their country, and is one way of linking Russia into a more universal system while maintaining differences with the West. The concept is at the core of today's Russian cultural and political self- understanding." For the Russian leadership and most of its citizens Russia deserves great power status by virtue of its history, culture, resources and territory (Popov 2015). That is, the status of great power is something natural for Russia and therefore should be treated as equal by other powers.

The self-assertion of being a great power follows the interests of the nation, and therefore the recognition of greatpowerness is also based on the country's interests and not on objective measures. Russia's external strategies are mostly aimed to gain great power recognition. For Russia's ambitions as a great power, material capabilities are of great importance. Nevertheless, the significance of material capabilities is the product of a process of social construction, and the result of that social construction is relevant as well (Leichtova 2014).

As argued, Russia's interests and security priorities are not only linked to a material level but to ideas as well related to its great power identity and the necessity for Russia to be recognised by the West as a great power. It should be noted that the West is an essential component in understanding how Russians have perceived themselves throughout history. This constructed category has changed over time: "the West" and "Europe" were sometimes identified as one, but they can now be separated. "Through debating Russia's relationship to this constructed category, the Russian elite pictured Russia as a nation and as an empire, identified paths for their country's modernizing political, economic and social reforms, analysed the place of individual in society, and dwelt on the role of religion in the modern world" (Tolz 2010: 197). Russia's status relative to the West is arguably the most important criteria in looking for a national identity. Historically, Europe/West is the significant Other in relation to which Russian identity is defined (Clunan 2009, 2014; Tsygankov 2010; Sergunin 2016; Smith 2016).

According to the official Russian narrative, one of the essential great power attributes that Russia is said to preserve is its military might. Notwithstanding the severe crisis that Russia's armed forces underwent, Russia continues to rely to a great extent on nuclear arms in order to preserve its great power status. Despite the significant reductions in Russian nuclear forces 
since 1992, Russia still possesses the largest nuclear stockpile in the world and is in the process of a large-scale modernisation of its nuclear weapons (Kristensen and Norris 2017). Accordingly, nuclear deterrent is essential for the containment of other great powers and the crucial source of its political and even economic position in world affairs (Karaganov 2010). What is more, Russia conceives of nuclear weapons as the ultimate guarantors of the security of the country. In 2014 Putin exhorted western countries "not to mess with Russia." Putin said, "Thank God, I think no one is thinking of unleashing a large-scale conflict with Russia. I want to remind you that Russia is one of the leading nuclear powers" (Parfitt 2014). Consequently, the Russian leadership sees as indispensable the preservation and modernisation of the country's nuclear forces, especially the strategic nuclear forces.

The self-image of Russia as a great power not only stems from its nuclear might, however. One of the key elements used to sustain Russia's aspirations to be a great power is its Asiatic Russia. In the last decade, Putin has been constructing the narrative that development of Siberia, the RFE and the Arctic will further the development of Russia and confirm its status as Euro-Asiatic power.

\section{ASIATIC RUSSIA}

From the Russian perspective, the way in which a great power should look like stems mainly from geopolitical elements. Under this narrative, one of the country's most important features is the geographic location between Europe and Asia. The unique size of Russia's territory and its historical development is a central element in Russia's great power identity (Leichtova 2014). The region historically defined as "Siberia" is essential in Russia's self-conceptualisation as a great power straddling the West and Asia. This means that, through Siberia, Russia embraces a unique Euro-Pacific identity in order to maintain its status as a great power. According to David Kerr (2009: 2), President Putin asserts "some version of the middle continent as a Russia-centred civilizational space that both separates and unifies East and West. Only in this way can Russia avoid the fate of being reduced to a regional power."

As Dmitri Trenin (2012) explains, Russia is a global power because of Asiatic Russia, and "without Siberia, Russia would no longer be Russia, but Moscovy." Arguably, one of the most important long-term factors influencing Russia's national identity was Russian expansion into Northern Asia with the conquest of Siberia. This great expansion fed into the Russian national idea 
and reinforced the necessity to be a great power from the era of Peter the Great onwards. The expansion of Russia to the Pacific coast transformed the country, from a landlocked eastern European state into an immense, multiethnic and bi-continental empire (Dmytryshyn 1991). Modern Russia owes to a great extent its status as a global power to Siberia, which makes Russia more than a "vast European country" (Dash 2010: 147).

Asiatic Russia not only comprises more than two thirds of the territory of Russia and about one tenth of the earth's land surface, but about 90 percent of the natural resources in the Russian Federation are located in Siberia such as gold, aluminium, coal, cellulose, gas, oil, diamond, timber, fisheries and water resources (Naumov 2006). Thus, it is in Siberia that not only the space but the resources that supports, in large part, Russia's claim to great power status, are located. Indeed, Asiatic Russia's resource-rich land was crucial in the rise of the Soviet Union as a superpower. Consequently, Siberia plays a key role for Russia; without Siberia, Russia "would be spineless" (Dash 2010: 147).

It is often argued that the geographical centre of gravity in international politics and economics is moving away from Europe and the Atlantic world to the Asia-Pacific region (Walton 2007; CSCAP 2010; Kizekova 2011) as this region has such a combination of wealth, resources, territory and strategic geography (Walton 2007). The alleged ongoing relocation of the world's affairs towards the Asia-Pacific region brings Asiatic Russia, and therefore, Russia, closer to this new centre of gravity in international politics, security and economics. In this sense, several Russian think-tanks close to the leadership, such as Valdai International Discussion Club, the Russian International Affairs Council (RIAC) and the Council for Security Cooperation in the Asia Pacific (CSCAP), have urged the government to implement a comprehensive strategy for the development and integration for Siberia. They assume that Russia's great power status depends, to a great extent, on Russia's international position in the Asia-Pacific region: Russia is a Euro-Pacific country and it should act accordingly. As per the CSCAP "[...] the fate of the Russian state as a global player would be increasingly determined by the place of its Asian part in the new economical order" (CSCAP 2010).

Nevertheless, the economic liberalisation in the 1990s had a negative impact on Asiatic Russia: subsidies from the government were drastically reduced and most of the incentives to live in the region were cut (Leshchenko 2010). The transition from a Soviet, centrally planned economy to a market economy had a negative impact on Siberia. According to a Moscow scholar Vladimir Portyakov, Russian Academy of Science (RAS) Institute of Far 
Eastern Studies (IFES), "Following the liberal reforms in the 1990s the government practically abandoned the region, and thus, Siberia and the RFE practically had to survive by their own" (pers. comm. 15 April 2015). This resulted in a significant deterioration of living standards.

The end of Soviet era policies and its catastrophic consequences for the region and a lifting of migration movements resulted in a huge exodus of population. This only accentuated the severe economic and social crisis that led to a further exodus of people from the region (Heleniak 2009). This had led to view Siberia as a zone of depopulation and decline. From 1989 to 2010 a gradual tendency of population decline was registered in practically all federal entities, data shows that only five federal entities out of 25 registered a positive demographic trend. It has to be underlined that the majority of entities registered intra-regional migration toward the regional centres whereas the population of industrial cities declined, although this decline slowed in the period 2002-2010. The situation is much bleaker in the mainland regions of the northeast and in cities along the eastern Arctic coastline; they registered a drastic population decline and even some settlements were totally abandoned, particularly in Magadan and Chukotka (data from ROSSTAT 2017).

Even though from 2010 to 2017 data still shows negative demographic trends in most towns of Siberia, especially in the RFE, the decline has considerably slowed and the population of many federal entities has remained more or less unchanged and only a few towns in the northeast still face a real threat of depopulation. According to an analytical report presented by the Russian think tank Valdai International Discussion Club (Karaganov 2016), by 2025 the demographic situation in Asiatic Russia would be stabilised.

Nevertheless, there are several internal socio-economic factors that hamper the development of the region. For instance, the average per capita income in most of Siberia's regions is lower than the national average, whereas the living costs remain considerably higher. In addition, environmental problems in industrial cities raise serious concerns within the local populations. In terms of infrastructure, healthcare institutions, entertainment facilities, education and culture institutions and research centres, the region lags behind.

The huge and growing imbalance between a vast resource-rich territory and the size of the population worries many in Russia. For economic and geopolitical reasons, the population decline contradicts Russian interests (Leshchenko 2010), especially in the RFE as the region is far and poorly connected to Russia's European core and uncomfortably close to the fast, dynamic Northeast Asian countries which lack some of the resources the region has in abundance. "In broader geopolitical terms, Moscow's authority 
continues to rest mainly on its political-military presence in the RFE - its industrial financial footprint in that part of the world is essentially insignificant" (Lee 2012). The government admits that the situation in the RFE is one of the most acute problems the country is facing. President Putin has described it as a threat to national security and that if concrete measures were not taken, the very existence of this region for Russia would be questionable (Rangsimaporn 2009). Similarly, Medvedev has stated that if Russia failed to develop the Russian Far East, it could lose it (Borodaevskiy 2011).

The crises in Siberia following the demise of the USSR reversed the four-hundred-year trend of eastward migration from European Russia started by the takeover of the Khanate of Sibir by Yermak. This, in the context of the ongoing shift of the world's economic and political centre from Europe to Asia and especially in the context of the rising China, provokes serious concerns within the Russian elite that in the long term the country could begin to effectively lose economic control and sovereignty over its eastern resourcerich and vast territories (Leshchenko 2010).

The Russian Empire sought the nominal control of much of Asiatic Russia. The region only began to play an important role for Russia in the first half of the twentieth century, when the Soviet Union began to industrialise and urbanise the vast region and set up new permanent settlements in order to exercise sovereignty and exploit natural resources. During Soviet industrialisation the resources located in Asiatic Russia began to play a crucial role in the Soviet centrally planned economy. A major industrial base was created, as well as a transport infrastructure. The Soviet government created many single-industry strategic towns and their development was considered a state priority. The Soviet Union put settlements and populations in some of the most isolated and coldest places on Earth due to the belief that in order to exert sovereignty all its territory must be populated and developed to be effectively possessed.

Most of the resources in Siberia were not fully exploited until the twentieth century. The vast and resource rich territory of Siberia was crucial in the rise of the Soviet Union as a superpower. As in Soviet times, Russia is now using the development of Asiatic Russia to legitimise to domestic and international audiences its great power aspirations. That is why for the Russian leadership potential threats - real or imagined - of the loss of economic or political control over Asiatic Russia are to the same as the loss of its sovereignty and therefore the loss of Russia's great power status. Thus, the regions' security issues are at the heart of Russian great power policies in Northeast Asia (NEA). Internal and external geopolitics of Siberia are closely interconnected. In the words of Natasha Kuhrt: 
What appear at first glance as purely domestic issues, such as migration and demographics, environmental degradation, and energy resources, can all be securitised and linked back into Russia's selfconceptualisation as either a successful "Great Power" on the path to modernisation or, conversely, as a declining resource base and "raw materials appendage (Kuhrt 2012: 472).

The preoccupation in Russia is that further economic integration with NEA would weaken the ties of Russia's eastern provinces with European Russia and strengthen the influence of other countries (China in particular) on Russia's east. Indeed, without China's rise, the issue of sovereignty might not be an issue at all. Russia's apparent vulnerability vis-á-vis China brings the region's security issues to the forefront.

\section{EXTERNAL STRATEGY: CHINA}

Russia's economic and security interests in Northeast Asia have considerably changed in the last few decades. Arguably, one of the most important factors contributing to this new reality is the rise of China. The Russia-China comprehensive strategic partnership is arguably one of the most important elements of the new world order and the achievements made by the two countries in the last two decades are noteworthy. Russian and Chinese leaders and scholars consider that the similarities in their worldviews are an important basis for their partnership and, in fact, the growing spheres of policy coordination reflect these shared political values (Ivanov 2016). Russia and China see multipolarity as the foundation of the global system and one of their major goals in building a partnership is to increase the influence of both countries in regional and international affairs. As Alexander Sergunin notes, "Russia and China constantly challenge the Western-led status quo and try to elevate their status with the help of each other" (pers. comm. 16 September 2016).

It can be said that their dissatisfaction with the United States role as the sole superpower and dominant pole was crucial in the Sino-Russian rapprochement. It should be noted that there is no a single factor, but many other local and regional factors contributing to the consolidation of a truly strategic partnership. According to Portyakov, "The Russia-China relationship is to a great extent self-sufficient, influence of external factors does exist, but in spite of all the changes it is possible to keep a normal level of relations" (pers. comm. 15 April 2015). 
Russia and China believe their bilateral relationship to be a "landmark" in world politics and a guarantee to peace and stability in the region and in the world, as well as being one of the most important elements of the new world order. Similarly, both sides believe that this relationship is not only the key to safeguarding their security, political and economic interests, but for promoting a more balanced, peaceful and just world order (Ivanov 2015, 2016).

Russia and China call their type of interaction a new form of great power relations, not a zero-sum relationship but a harmonious and friendly coexistence between two world powers (Yu 2007; Xinhua 2014). The Russian and Chinese leaderships, state media and many analysts claim that the state of their bilateral relationship is at its highest point and describe it as the best in history, saying that there are no serious issues that cannot be resolved. In the words of Fudan University scholar Zhao Huasheng, "There has never before been a time when relations were both stable and close for such a lasting period" (pers. comm. 10 October 2013). Nevertheless, it has to be emphasised the fact that an important part of this partnership is still played by the leaderships of Russia and China, consequently, both sides face several challenges in converting the achieved level of political cooperation to practical cooperation in other fields.

One natural question is whether the Russia-China strategic partnership is moving toward a formal alliance. Some analysts express their concern that China and Russia are gradually building an anti-Western Alliance (Chen 2014). Some others disagree and predict that the partnership is not feasible in the long-term, pointing out the problems such as historical mistrust, competitors and conflicting interests. Russian and Chinese mainstream analysts believe that the shortcomings of the relationship are often highlighted in the West, because they fear that Russia and China could join forces against the West.

The majority of Chinese and Russian scholars interviewed by the author believe that the partnership has solid foundations and underline the fact that there are several strategic reasons and mutual needs behind it. Russian scholars frequently claim that the continuation of the aggressive policies of the United States and its allies towards Russia and China could bring both countries even closer. Vladivostok scholar Artyom Lukin from Far Eastern Federal University (FEFU) suggests that at the global level, the United States is pushing Russia and China together, and this could eventually lead to an institutionalised alliance that would bring the world back to bipolarity (pers. comm. 30 October 2013). In this sense, Vladimir Portyakov argues that "the recent deterioration of West-Russia relations would not lead to a formal alliance but could move the partnership in that direction. For many people 
in Russia, current threat from the West is more dangerous than the potential hypothetical threat from the rise of China" (pers. comm. 15 April 2015).

In China, scholars characterise China's relations with Russia as adhering to the three "noes" policy: non-aligned, non-confrontational and not directed against third parties (Sautin 2018, Yu 2007). In fact, the three "noes" policy is the cornerstone of China's foreign policy. Indeed, the Soviet Union has been the only country with whom China has established an alliance, and it was a negative experience. Therefore, it is often emphasised by Chinese scholars the three "noes" policy when dealing with Russia. For instance, Chinese scholar Yi Jiang, Institute of Russian, Eastern European and Central Asian Studies (IREECAS) stresses the fact that "Russia is a partner of China but not an ally" (pers. comm. 23 October 2013). Liu Fenghua from IREECAS argues that for China "an alliance would provoke a serious confrontation with the West and lead to destabilisation of the region" (pers. comm. 23 October 2013). China rejects any sort of alliance, as its own foreign policy principle, and the topic is taboo in the official discourse.

Beijing scholar Ding Xiaoxing, China Institutes of Contemporary International Relations, considers that "the Russia-China relationship is based on political and security issues, unlike other great power relationships" (pers. comm. 23 October 2013). Pressure from the United States did accelerate the Sino-Russian rapprochement; nevertheless, the partnership is not casual but was a strategic choice made by the two countries. Vladimir Potryakov notes that "Russia and China strive to influence the whole world, and the international structure and in this regard the partnership, is beneficial. Russia and China have constructed a truly strategic partnership" (pers. comm. 15 April 2015).

Russia's relationship with China should not be viewed only within the matrix of multipolarity and geopolitical counterbalance to the United States, but also within the context of Russia's self-conception as a great power. It seems crucial for Russia's aspirations to maintain more or less balanced relations with China. The rapid development of China constitutes a potential security threat - real or imagined - to Russia's greatpowerness. As argued, Russia's evolving strategies are in part shaped by the leadership and the elite's perception of what great power is and the place of Asiatic Russia in the country's great power identity.

One of the major concerns of the Russian leadership constitutes the growing economic and demographic asymmetry between the densely populated regions in Northeast China and the sparsely populated RFE. The RFE accounts for one third of the country's territory, 6.2 million square kilometres, and it is inhabited by only 6.2 million people, resulting in a population density of one 
person per square kilometre. Indeed, if it was an independent country, the RFE would be the least populated country in the world (data from ROSSTAT 2010). In contrast, Northeast China-Heilongjiang, Jilin, Liaoning, Inner Mongolia provinces - has a population of 133 million and a population density of 67.2 persons per square kilometre (data from Chan 2013).

This demographic imbalance along the Russia-China border began to receive more attention following the collapse of the Soviet Union amid the massive out migration from Siberia and the RFE to European Russia. The idea of many potential Chinese migrants coming to settle in Russia and the eventual takeover of a rising China over the underpopulated rich-resource region began to spread in the West and in Russia as well. The low population density of the RFE compared to that of Northeast China does not actually mean the Chinese are taking the RFE over, however. "The natural population imbalance is neither a necessary nor sufficient condition for migration" (Korolev 2015). It should be noted that this population imbalance along the Russian-Chinese border has existed since Russia expanded into the Pacific in the seventeenth century and was much greater than it is now. Indeed, most of Chinese migrants entering to Russia annually are temporary workers that return to China after their stay in Russia (Larin 2011). Andrey Ostrovskiy from the RAS IFES notes, "There is a wide consensus among Russian experts that the number of Chinese citizens living and entering Russia has been overestimated and there is no Chinese expansion into the RFE" (pers. comm. 15 April 2015).

Population trends in China have been gradually decreasing, in fact, China's total fertility rate crossed the 2.1 replacement rate in the $1990 \mathrm{~s}$ and it is now around 1.6 births per female. This has led some experts in Russia to call China's demographic expansionism into question, as China "will need its working population at home in years to come" (Korolev 2015). Zhao Huasheng is representative of a faction of Chinese scholars that downplays the threat of massive immigration by placing the relatively small-scale migration trend (pers. comm. 10 October 2013). Specialist Ding Xiaoxing goes one step further, suggesting that "the current economic and demographic trends in Northeast China are already reversing the northward flow of Chinese workers into Russian territories" (pers. comm. 23 October 2013). According to the scholar, "the Russian Far East is not an attractive place for us to live; it is a cold and isolated place." What is more, "people in China do not want to live even in the north-eastern part of our country where climate conditions are similar to that in Russia's bordering regions" (pers. comm. 23 October 2013).

From the interviews taken with Chinese scholars, it could be said that the issue is often exaggerated and that illegal migrants actually stay in Russia 
only for a short period and then return. Indeed, not only are Chinese migrants not coming to the RFE but there is a pattern of internal migration from China's north-eastern provinces southwards. The three north-eastern provinces in China, Heilongjiang, Jilin and Inner Mongolia, have a net out-migration (data from Chan 2013). In the opinion of a Russian expert, "[...] the Chinese government is having problems keeping its population from moving south. They are having the same problems of people leaving their northern territories as we are having with the Far East" (Korolev 2015).

The large demographic asymmetry in bordering areas between the two countries will remain a "minus" for Russia in the foreseeable future (Portyakov 2013). Arguably even this little minus is taken seriously by the Russian government. According to Kashin (2013), "all precautions taken by Russia are associated not with a direct but potential threat to its interests, sovereignty and territorial integrity that may come from China. And yet, even a potential Chinese threat is a significant factor in Russia's foreign and defence policy." Arguably, the China factor plays a very important role in Russia's nuclear policy in Asia, as Russia's defence capabilities with regard to China are based on nuclear weapons. This can probably partly explain why Russia declines any further cuts in nuclear arsenals and also their reticence to disclose the composition of its tactical nuclear weapons (Kashin 2013).

Arguably, economic ties are the weakest link in the bilateral relationship, playing a minor role, and this is expected to continue. Economic cooperation is still low but it is likely to increase. According to Xin Zhang, East China Normal University, "Given the existing impediments and difficulties, however, the relationship is possibly not desirable, but is acceptable" (pers. comm. 17 October 2013). It could be said that Russia and China are not very effective partners in the economic dimension. They are more effective in global and regional politics where they have similar interests and common approaches. That is why the focus of the bilateral relationship is generally on that area (Larin 2011). It is often emphasised by the elites that the economies complement each other. From 2000 to 2014 bilateral trade increased more than 15 times, from USD 5.72 billion to USD 95.3 billion (Synyakova 2014). China and Russia agreed to boost the trade level to USD 100 billion in 2015 and to USD 200 billion by 2020. This positive dynamics, however, failed to prevent Russia-China trade from declining to USD 66 billion in 2015 (Ivanov 2016). Bilateral trade increased to USD 69 billion in 2016 and reached USD 84 billion in 2017 (Ivanov 2017). Nevertheless, the total trade volume is still far from the goal set by both countries in 2010 .

It should be noted that the economic relationship is becoming more unequal in terms of GDP, and the roles of both countries have reverted. The 
structure of the Russo-Chinese economic relationship reflects the role of the two countries in the world economy. Hydrocarbons still prevail in the structure of Russia's exports to China. In 2016 they amounted to 64 percent of Russia's total exports to China, wood accounted for nine percent, machinery and fish four percent each, and others 19 percent (Karaganov 2017). Whereas Russia's exports of machinery and ferrous metals have drastically decreased, the share of oil and oil products in exports to China has drastically increased in the last 15 years.

The main field of Russia-China cooperation in Siberia and the Russian Far East is energy. The gas contract signed in May 2014 can be considered a breakthrough in Russia-China economic relations in general, and for the joint development of the RFE and Northeast China as it is the biggest contract for energy in the history of Russia and the USSR. Russia will supply 38 billion cubic metres of gas per year, although deliveries could increase up to 50-55 billion cubic meters per year. The contract's value included the construction of a $4000 \mathrm{~km}$ long pipeline called "Power of Siberia" to transport the gas across Eastern Siberia. Chinese aspirations to diversify and secure its energy sources are matched by Russia's national strategy to diversify its energy exports. The long-term provision of natural gas is extremely important for the energy balance as well as for the sustainable development of Northeast China as the region is cut off from the unified East-West gas transportation system (Gryvach 2014). It could be argued that the gas deal makes Russia more dependent on China, but it could also be said that China is becoming more dependent on Russia as well (Maslov 2014).

According to Zhao Huasheng, China is gradually paying more attention to the RFE as the country's energy and other natural resources do not satisfy its modernisation. China has to guarantee the supply of these resources, and so it becomes a security issue. In the words of Zhao Huasheng "the abundant reserves of Siberia and the RFE are the closest and the safest to China, thus, supply from Russia is the key to securing and diversifying their supply of energy and other natural resources" (Zhao 2016). Nevertheless, and despite several agreements on energy, Russia is still on the periphery of Chinese energy market, and China is in no hurry to expand bilateral cooperation (Golobokov 2017).

Russian scholars and think tanks close to the government have urged the leadership to identify other competitive advantages of the region in order to diversify exports to China; to evaluate the possible demand for certain goods from Siberia in China, and to find points and areas of complementarities and coincidences and work along these lines. According to these analyses, despite 
the rapid increase and dynamism of Asian economies, their economic growth has fundamental restrictions due to the lack and exhaustion of resources. In the twenty-first century, when talking about natural resources, nations have to take into account three variables: climate change, shortages of fresh water and deficits of food (Likhacheva et al. 2010; Ivanov 2015; Karaganov 2012, 2017). Moscow scholar Igor Makarov for instance, argues that "water is one of the limitations to China's economic growth, and thus water-intensiveindustries is a good opportunity niche for Russia" (pers. comm. 16 April 2015). The abundance of water in Siberia makes industries requiring much water consumption less costly. Russia could offer its own water resources, instead of just trading water as crude oil or gas, which is complicated and inefficient, focusing on the market for virtual water by exporting water-intensive products to countries where it is more expensive (Karaganov 2012).

As the development of Siberia and the RFE has become a national strategic priority for Russia, this provides space for regional cooperation between China and Russia. Similarly, China would like to see further economic cooperation with Russia in the development of its northern provinces. "The positive interaction of Russia's eastern region development and the revival of northeast China will promote mutually beneficial cooperation in the two countries border areas" (Sha 2014). Seemingly, the Chinese leadership understands the major role the country is likely to play in the development of Asiatic Russia. From the perspective of some Chinese scholars, "Siberia and the Russian Far East require stable investment, but the Russian government cannot currently invest all the resources needed for development. China possesses sufficient financial reserves, which it can use to develop and modernize Siberia and the Russian Far East" (Ivanov 2015: 16).

It is frequently argued in Russia that China cannot be the main partner for developing Russia's eastern provinces (Inozemtsev 2012; Trenin 2003). By the same token, it is said that if the RFE becomes a raw material appendage of China, Russia would become a junior partner of China. Fyodor Lukyanov (2015) argues that in fact Russia is a raw materials appendage of the European Union and it has not become its junior partner. Indeed, "China and Russia both suffer from the consequences of resource vulnerabilities, but Russia's fears of becoming China's resource appendage are more widely discussed" (Wishnick 2016: 11). Moscow scholar Igor Makarov argues, it is utopian to think that anyone is acceptable except China for the projects of development in the RFE as the development of Siberia is impossible without China as a priority partner (pers. comm. 16 April 2015).

Trade between the RFE and China has gradually developed in the last decade. Indeed, China became the most important economic partner for the 
RFE in 2016. The total trade that year between the RFE and China totalled USD 6.13 billion, South Korea ranked second among RFE's partners (USD 5.51 billion), and Japan was third (USD 5.21 billion) (Qin 2018). It should be highlighted, however, that in 2016 China was only the main partner for the border provinces of the Russian Far East, but not for other provinces (Ivanov 2017). China plays a key role for the RFE; it has a special place in the economic strategy of the region. Following the crisis in Ukraine, Russia has moved closer to China and even has taken steps to allow the direct participation of China in the RFE by lifting restrictions on Chinese investments in the region (Lukin 2015). This breakthrough in energy came in 2014, when Rosneft and CNPC signed a framework agreement for the purchase of a 10 percent stake in Russia's oil-rich Vankor field by the Chinese company. As a matter of fact, this was the first time Russia has made that kind of offer of a strategic asset to another country. This gradual involvement could be seen as a natural step in the development of the strategic partnership following the crisis in the Ukraine.

In this situation, the question for Russia seems not to be partnership with China for the development of Russia's east, but how Russia can find a model to develop economic ties with China, along with political and security issues. Russian elites often "securitise" relations with China, in particular its economic relations whereas Chinese scholars "desecuritise" by downplaying any threat. The issue, however, is not that Russia could become a resource supplier to China but the fact that giving privileged access to the Chinese to the RFE would exclude foreign investors, namely Japanese and Koreans. In fact, this situation can be seen now in the region, as noted by Makarov, "Japanese and Korean investors are reluctant to participate in regional projects because they cannot compete with the Chinese, their presence is too strong" (pers. comm. 16 April 2015).

Russia constantly securitises economic relations as exclusive Chinese economic presence in the region would probablyjeopardise Russia's sovereignty over its eastern provinces. "In the Russian Far East, Russia has securitised issues of migration and cross-border trade, highlighting the fact that a more populous China might eventually effect a peaceful takeover of the region by economic means alone" (Kuhrt 2015: 80). In the long term, the viability of the Russia-China strategic partnership will depend to a great extent on whether Russia can successfully develop Siberia, and especially the RFE. The risks of regional cooperation with China might not be a massive invasion/incursion of Chinese citizens to the RFE, but the fact that an economic "sinicisation" of the region could lead to a certain erosion of Russia's sovereignty and therefore 
decisive in that matters related to the region would not be decided in Russia, and according to Russia's natural interests, but more according to Chinese interests (Lukin 2015).

Being at the confluence of two worlds - East and West—has had longterm influence on how Russia has thought of its national identity, in particular prompting the question: to what extent is it joining or resisting these two worlds? In this case, is Russia joining or resisting Asia? What role does China play in this endeavour?

Russia is geographically very much part of Asia, but compared to Europe, Russia's ties with Asian countries are less developed. Russia is considered an economically, politically and culturally distant neighbour (Akaha and Vassilieava 2009). Russian scholars understand that Asian states "often do not regard Russia as an Asia-Pacific country, because its demography, economy and politics largely follow European patterns" (Karaganov 2014: 9). The mere existence of Asiatic Russia is not sufficient basis for Russia being recognised as an Asian power. Russia's pivot to Asia initiated as a long-term rebalancing project under Putin's administration, aimed mostly to maintain its global power identity by preserving Russia's freedom of manoeuvrability and independence in world affairs. Nevertheless, this pivot remains mostly unsubstantiated in terms of foreign policy, and is not as clear as sometimes Russia's rhetoric suggests.

One of the main challenges Russia faces in engaging Northeast Asia, is that Russia is in Asia but it is not Asian. In the case of China, there are ambivalent attitudes of Chinese scholars towards Russia's "shift" to Asia. For instance, Xin Zhang believes that East Asia has become Russia's second foreign policy priority, only after Europe (pers. comm. 17 October 2013). Beijing scholar Yi Jiang suspects that East Asia is not a top foreign policy priority for Russia, as the country thinks of itself as essentially European. "Russia's focus on Asia is above all rhetorical, there has not been a dramatic change in the attitudes of the Russian elite toward Asia." For him, "East Asia is only Russia's fourth priority after Europe, Central Asia and North America" (pers. comm. 23 October 2013). In this sense, Lui Fenghua argues that Russian elites are "still Europeanised, they only talk about Russia's pivot to Asia, but nothing more" (pers. comm. 23 October 2013).

Russia's efforts to develop Siberia and the RFE and to integrate the region into Northeast Asia are seen from different perspectives in China. In this regard, Xin Zhang considers that "Russia is moving in the right way for development of its eastern region; however, it is an enormous endeavour that will take decades" (pers. comm. 17 October 2013). Some Chinese scholars 
consider that the lack of integration between Asiatic Russia and Northeast Asia might not be the business environment per se or structural issues of the Russian economy, but the fear of any integration process. In this sense, Yi Jiang argues that Russia is not really committed to integrating Asiatic Russia into Northeast Asia (pers. comm. 23 October 2013). By the same token, Beijing scholar Liu Fenghua from emphasises that Russia "fears any sort of integration of the RFE into Asia." According to him, "Russians do not want even to hear the word "integration." Liu argues that "Russia fears any kind of integration because the country has not received enough benefit from the globalisation process. On the contrary, China supports the idea of integration as it has received tangible benefits from the globalisation process" (pers. comm. 23 October 2013). In this sense, China sees itself as open to the world, pro-market; in contrast, Russia is seen as more insular and nationalistic, especially in regards to trade. The Chinese scholar notes, however, that "Russia has to develop Siberia and the Russian Far East before any process of integration, otherwise, any process of integration would fail" (pers. comm. 23 October 2013).

As Russia is trying to integrate itself into the Asia-Pacific region, the role of Russia's soft power appears to be crucial; Russia needs to intensify peopleto-people exchanges (language, education, science, culture, youth exchanges), not only with NEA but with other countries as to strengthen its presence in Asia and its position vis-á-vis China. Vladivostok scholars argue that soft power in Asia-Pacific region "is becoming one of the most important national interests of the country in terms of foreign policy" (Bobylo and Sevastyanov 2016). Accordingly, in the short term, Russia should pay attention particularly on developing bilateral ties in the region focusing on the development of scientific, technical and economic projects as this would strengthen people-topeople exchanges (Bobylo and Sevastyanov 2016).

Elizabeth Wishnick (2016) notes that Russia's pivot to Asia embodies the contradiction between a privileged relationship with China, based on their shared positions on key global issues, and the expansion of Russia's multilateral and bilateral ties seen as necessary to strengthen the Russian presence in the Asia-Pacific region. Marlene Laruelle (2014) observes that in Asia China "presents itself as the main identity dilemma for Russia." China simultaneously reinforces and potentially threatens Russia's greatpowerness. Natasha Kuhrt (2015: 84) synthetises the current state of the situation: "Both at the regional and global levels, China's economic performance implicitly challenges Russia's claim to be a great power, and the possibility that at some unknown point in the future this economic power might be translated into political power poses a threat to Russia." Indeed, without China's rise, the issue 
of sovereignty over the RFE might not be an issue at all. The more unequal the relationship grows in terms of the balance of power, the more fearful Russia will be of China's presence in its eastern provinces. In contrast, if Russia can maintain a fairly balanced relationship, the more confident Russia will be in the relationship of its Asian region with China. As the Russia-China strategic partnership advances, the analysis of relations at a regional level can serve to assess the actual state of the overall bilateral relations.

\section{CONCLUSION}

The Russian leadership has established a narrative on Russia as a global power. In fact, under this narrative being a great power is the condition of possibility for the existence of Russia as a nation. This greatpowerness has an important role in Russia's domestic policies and external relations of Asiatic Russia. Nevertheless, Russia's self-conceptualisation as a great power provokes numerous confrontations and discrepancies when it comes to Russia's relations with China. This article aimed to examine the dilemmas between cooperation and security issues and the way China simultaneously reinforces and potentially threatens Russia's greatpowerness. Asiatic Russia embodies Russia's great power dilemmas between security concerns and international cooperation.

For Russia, the importance of the partnership with China is essential to the security of the RFE and it legitimates to a certain extent Russia's claims to great power status. The main field for Russia-China cooperation in Siberia and the Russian Far East is energy. The aspirations of China to diversify and secure their energy sources are matched by Russia's national strategy to diversify its energy exports. Nevertheless, to assert its identity as a power in Asia, Russia requires to diversify its exports and develop relations with other states, Japan and South Korea in particular. Despite Russia's diversification attempts, however, the relationship with China remains central to Russia's Asia-Pacific policy and the Russian elites understand the fact that China will remain the key partner, at least in the foreseeable future. Exclusive Chinese economic presence in the RFE could eventually threaten Russia's sovereignty over its eastern provinces. This goes against Russia's strategy to become an Asian power and therefore to be recognised as a global great power. For Russia it seems of extreme importance that China does not have hegemonic access. In this sense, Japan and South Korea could actually reinforce Russian sovereignty over the region. The seemingly growing dependence on China 
especially after the crisis in Ukraine brings the region's security issues to the forefront.

The strategic partnership with China is essential in Russia's great power aspirations as it enables the country to challenge the United States-led international order and to become a centre of power in Eurasia. Thus, one of the main goals of Russia in partnering with China is to become one of the centres of power in the new world arena. The result of this attempt is unknown, and if Russia weakens vis-à-vis China, Russia's pursuit of a multipolar world could only help the emergence of a bipolar system—a bipolar order between China and the United States. It seems crucial for Russia's aspirations to maintain more or less balanced relations with China. The gap between national economies is only likely to widen whereas the gaps in other fields in which Russia has an advantage are likely to reduce. Global factors, as well as Russia's and China's internal factors, will determine whether Russia can maintain comprehensive power vis-à-vis China or whether the balance of power will move completely into China's favour.

The rise of China presents a major dilemma for Russia: on the one hand, Russia's actual engagement with China substantiates its identity as a global power; on the other hand, at a regional level China embodies a potential menace - real or imagined - to Russia's greatpowerness. In this sense, the analysis of interaction and cooperation between Asiatic Russia and China could serve as a barometer of the actual state of the overall bilateral relations.

\section{NOTES}

* Rafael Contreras-Luna is an associate professor in the Department of History and International Relations at Samara National Research University S. P. Korolyev, Russia. He received in 2017 his PhD from Durham University, United Kingdom. He holds a master's degree from Saint Petersburg State University and a bachelor's degree from Ibero-American University, Mexico City. He is a member of the Centre for Eurasia Studies at Metropolitan Autonomous University, Mexico City; and Occasional Visiting Professor in the Department of International Relations and Foreign Languages at Peter the Great St. Petersburg Polytechnic University, Russia. His research concerns politics in the Asia-Pacific region and in the Arctic; Russia's domestic politics and Russia's foreign policy in Northeast Asia; and Russia-China/Russia-United States space cooperation. He teaches on Russia's relations with countries of Northeast Asia, Russia in global affairs, regional aspects of international relations, and political philosophy. He has recently published about strategic interests of Russia and Northeast Asia in the Arctic, and about Russia-South Korea contemporary relations. 


\section{REFERENCES}

Akaha, T. and Vassilieva, A. 2009. Where in East Asia is Russia? Implications for regional integration. California: Monterey Institute of International Studies.

Billington, J. 2004. Russia in search of itself. Baltimore: Johns Hopkins University Press.

Bobylo, A. and Sevastyanov, S. 2016. Russia's "soft power": Asia-Pacific vector. Ojkumena 4: $75-85$.

Bogaturov, A. and Shakleyina, T. 2004. The Russian realist school of international relations. Communist and Post-Communist Studies 37: 37-51, https://doi.org/10.1016/j. postcomstud.2003.12.002.

Borodaevskiy, A. 2011. Historic choices for Russia. Japan Times, 18 November. http://www.japantimes.co.jp/text/eo201111118ab.html (accessed 25 September 2015).

Cadier, D. and Light, M. 2015. Russia's foreign policy: Ideas, domestic politics and external relations. New York: Palgrave Macmillan.

Campbell, D. 1998. Writing security: US foreign policy and the politics of national identity. Minneapolis: University of Minnesota Press.

Chan, K. 2013. China: Internal migration. The encyclopedia of human migration. http://onlinelibrary.wiley.com/doi/10.1002/978144351071.wbeghm124/abstract (accessed 16 February 2017).

Chen, D. 2014. Are China and Russia moving toward a formal alliance? The Diplomat, 30 May. http://thediplomat.com/2014/05/are-cchina-and-russia-moving-toward-aformal-alliance/ (accessed 15 February 2017).

Clunan, A. 2009. The social construction of Russia's resurgence: Aspirations, identity and security interests. New York: John Hopkins University Press.

2014. Historical aspirations and the domestic politics of Russia's pursuit of international status. Communist and Post-Communist Studies 47: 281-290, https://doi.org/10.1016/j.postcomstud.2014.09.002.

Council for Security Cooperation in the Asia Pacific (CSCAP). 2010. Going east: Russia's Asia-Pacific strategy. Russia in Global Affairs, 4, http://eng.globalaffairs.ru/ number/Going-East-Russias-Asia-Pacific-Strategy-15081 (accessed 2 June 2016).

Danilova, E. 2017. Greatpowerness in the mass consciousness of Russians as an internal political basis of the Russian Federation national branding. Vlast' 9: 93-99.

Dash, P. L. 2010. Imagining a Russia minus Siberia: Issues and implications. In Asiatic Russia: Partnerships and communities in Eurasia, ed. Chatterjee, S., 139-152. New Delhi: Shipra.

Dmytryshyn, B. 1991. The administrative apparatus of the Russian colony in Siberia and northern Asia, 1581-1700. In The history of Siberia: From Russian conquest to revolution, ed. Wood, A. London: Routledge.

Gadzhiev, R. 2009. Problems of national identity quest in modern Russia. Vlast' 5: 15-17.

Gryvach, A. 2014. Window to Asia. Russia in Global Affairs, 2 July. http://www. globalaffairs.ru/number/Okno-vAziyu-16777 (accessed 15 March 2017).

Golobokov, A. 2017. The role of Russia and China in creation of energy security regional model in North-East Asia. Ojkumena 1: 163-171. 
Heleniak, T. 2009. Growth poles and ghost towns in the Russian Far North. In Russia and the North, ed. Wilson, E., 129-163. Ottawa: University of Ottawa Press.

Inozemtsev, V. 2012. Continent Siberia. Russia in Global Affairs, 4. http://eng.globalaffairs. ru/number/Continent-Siberia-15820 (accessed 6 August 2015).

Ivanov, I. (Ed). 2015. Development of Russian-Chinese trade, economic, financial and cross-border relations. Working paper 20/2015, Russian International Affairs Council (RIAC), Moscow.

2016. Russian-Chinese dialogue: The 2016 model. Working paper 25/2016, Russian International Affairs Council (RIAC), Moscow.

2017. Russian-Chinese dialogue: The 2017 model. Working paper 33/2017. Russian International Affairs Council (RIAC), Moscow.

Karaganov, S. 2010. Global zero and common sense. Russia in Global Affairs, 7 July. http://eng.globalaffairs.ru/number/GlobalZeroandCommonSense-14889 (accessed 15 March 2017).

Karaganov, S. (Ed.). 2012. Toward the great ocean, or the new globalization of Russia. Moscow: Valdai Discussion Group Analytical Report.

. 2014. Toward the Great Ocean-2, or the new globalization of Russia. Moscow: Valdai Discussion Group Analytical Report.

2016. Toward the Great Ocean-4: Turn to the East. Moscow: Valdai Discussion Group Analytical Report.

. 2017. Toward the Great Ocean-5: From the turn to the East to greater Eurasia. Moscow: Valdai Discussion Group Analytical Report.

Kashin, V. 2013. The sum total of all fears. Russia in Global Affairs, 3. http://eng. globalaffairs.ru/number/The-Sum-Total-of-All-Fears-15935 (accessed 15 March 2017).

Kerr, D. 2009. Dilemmas of the 'Middle Continent': Russian strategy for Eastern Eurasia. The International Spectator 44 (2): 75-94, https://doi.org/10.1080/0393272090290 9191.

Kiseleva, Y. 2015. Russia's soft power discourse: Identity, status and the attraction of power. Politics 35 (3-4): 316-329, https://doi.org/10.1111/1467-9256.12100.

Kristensen, H. and Norris, R. 2017. Russia's nuclear forces, 2017. Bulletin of the Atomic Scientists 73 (2).

Kizekova, A. 2011. Russia's role in EAS: Promoting inter-regional cooperation. Pacific Forum CSIS 62.

Korolev, A. 2015. The strategic alignment between Russia and China: Myths and reality. The Asan Forum, 30 April. http://www.theasanforum.org/the-strategic-alignmentbetween-russia-and-china-myths-and-reality (accessed 15 March 2017).

Kuhrt, N. 2012. The Russian Far East in Russia's Asia policy: Dual integration or double periphery? Europe-Asia Studies 64 (3): 471-493, https://doi.org/10.1080/0966813 6.2012.661926.

2015. Russia and Asia-Pacific: Diversification or sinocentrism. In Russia's foreign policy: Ideas, domestic politics and external relations, eds. Cadie, D. and Light, M., 175-189. New York: Palgrave Macmillan.

Laruelle, M. 2008. Russian Eurasianism: An ideology of empire. Washington, D. C. and Baltimore: Woodrow Wilson Center Press and Johns Hopkins University Press. 
2014. Russia's national identity and foreign policy toward the Asia-Pacific. The Asan Forum, 25 January. http://www.theasanforum.org/russias-national-identityand-foreign-policy-toward-the-asia-pacific/ (accessed 15 March 2017).

Larin, V. 2011. Russia and China: New trends in bilateral relations and political cooperation. In From APEC 2011 to APEC 2012: American and Russian perspectives on AsiaPacific security and cooperation, eds. Azizian, R. and Lukin, A. Honolulu: AsiaPacific Center for Security Studies; Vladivostok: Far Eastern Federal University Press.

Lavrov, S. 2012. Russia in the 21st-century world of power. Russia in Global Affairs, 4. http://eng.globalaffairs.ru/number/Russia-in-the-21st-Century-Worldof-Power-15809 (accessed 15 March 2017).

Lee, R. 2012. The Far East between Russia, China, and America. Foreign Policy Research Institute, 27 July. http://www.fpri.org/articles/2012/07/far-east-between-russiachina-and-america (accessed 15 March 2017).

Leichtova, M. 2014. Misunderstanding Russia: Russian foreign policy and the West. London: Ashgate.

Leshchenko, Y. 2010. Problems of the sociodemographic development of Siberia. Studies on Russian Economic Development 21 (6): 638-643, https://doi.org/10.1134/ S1075700710060079.

Light, M. 2003. In search of an identity: Russian foreign policy and the end of ideology. Journal of Communist Studies and Transition Politics 19 (3): 42-59, https://doi. org/10.1080/13523270300660017.

Likhacheva, A., Savelieva, A. and Makarov, I. 2010. Daily bread and water. Russia in Global Affairs, 3. http://eng.globalaffairs.ru/number/Daily-Bread-and-Water-15003 (accessed 15 March 2017).

Lukin, A. 2003. Russia between East and West: Perceptions and reality. Paper presented at the Joint Session of the European Consortium for Political Research, 28 March-2 April 2003, Edinburgh.

2015. Why the Russian Far East is so important to China. The World Post, 12 January. http://www.huffingtonpost.com/artyom-lukin/russian-fareastchina_b_6452618.html (accessed 15 March 2017).

Lukyanov, F. 2013. Why Russia's soft power is too soft. Russia in Global Affairs, 1 February. http://eng.globalaffairs.ru/redcol/Why-Russias-Soft-Power-Is-TooSoft-15845 (accessed 15 March 2017).

2015. Russia must exploit its pivot to the East (Op-Ed). Russian in Global Affairs, 26 June. http://eng.globalaffairs.ru/redcol/Russia-Must-Exploit-Its-Pivot-East-OpEd-17545 (accessed 15 March 2017).

Maslov, A. 2014. Not only gas. Russia in Global Affairs, 27 May. http://www.globalaffairs. ru/global-processes/Negazom-edinym-16658 (accessed 15 March 2017).

Morozov, A. 2015. Post-Crimea consensus. Russkii Zhurnal, 19 January. http://www.russ. ru/Mirovaya-povestka/Postkrymskijkonsensus (accessed 7 October 2016).

Naumov, I. 2006. The history of Siberia. London and New York: Routledge.

Neumann, I. 1996. Russia and the idea of Europe: A study in identity and international relations. London: Routledge.

Russia as a great power, 1815-2007. 2008. Journal of International Relations and Development 11: 128-151, https://doi.org/10.1057/jird.2008.7. 
2015. I remember when Russia was a great power. Journal of Regional Security 10 (1): 5-16.

Nye, J. 2013. What China and Russia don't get about soft power. Foreign Policy, 29 April. http://foreignpolicy.com/2013/04/29/what-china-and-russia-dont-get-about-softpower/ (accessed 15 March 2017).

Parfitt, T. 2014. Vladimir Putin issues new 'large nuclear power' warning to West. The Telegraph, 15 October. http://www.telegraph.co.uk/news/worldnews/vladimirPutin/11167192/Vladimir-Putin-issues-new-large-nuclear-power-warning-toWest.html (accessed 17 May 2017).

Popov, G. 2015. Russia's greatpowerness in the twenty first century. Mir Novoy Ekonomiki 4: $12-20$.

Portyakov, V. 2013. Russian-Chinese relations: Current stage and future prospects. Russian Analytical Digest 73: 2-4.

Qin, D. 2018. Chinese investment in the Russian Far East: The current status and problems. Ojkumena 2: 151-160, https://doi.org/10.24866/1998-6785/2018-2/151-160.

Rangsimaporn, P. 2006. Interpretations of Eurasianism: Justifying Russia's role in East Asia. Europe-Asia Studies 58 (3): 371-389, https://doi.org/10.1080/09668 130600601750.

2009. Russian perceptions and policies in a multipolar East Asia under Yeltsin and Putin. International Relations of the Asia-Pacific 9: 207-244, https://doi. org/10.1093/irap/lcn027.

Russian Federal State Statistics Service (ROSSTAT). 2017. Regions of Russia. http://www.gks.ru (accessed 18 May 2017).

Sautin, Y. 2018. Sino-Russian military relations: Gratitude and resentment. Center for Advanced China Research, 1 May. https://www.ccpwatch.org/singlepost/2018 /05/01/Sino-Russian-Military-Relations-Gratitude-and-Resentment (accessed 21 July 2018).

Sergunin, A. 2004. Discussions of international relations in post-communist Russia. Communist and Post-Communist Studies 37: 19-35, https://doi.org/10.1016/ jpostcomstud.2003.12.007.

2016. Explaining Russian foreign policy behavior. Stuttgart: Ibidem-Verlag.

Sha, L. 2014. The Far East fortune. Beijing Review, 6 February. http://www.bjreview.com. cn/quotes/txt/2014-05/20/content594213.htm (accessed 16 February 2017).

Shakleyina, T. 2012. Russia and the US in world politics. Moscow: Aspekt Press.

Smith, H. 2016. Putin's third term and Russia as a great power. In Eurasia 2.0: Russian geopolitics in the age of new media, eds. Bassin, M. and Suslov, M., 125-148. Lanham, Maryland: Lexington Books.

Synyakova, A. 2014. Russian-Chinese economic relations: The Korean aspect. In Russia and Korea in the changing world, ed. Zhebin, A. Moscow: IFES RAS.

Tolz, V. 2010. The West. In A history of Russian thought, eds. Leatherbarrow, W. and Offord, D. Cambridge: Cambridge University Press.

Trenin, D. 2003. Euro-Pacific nation. Russia in Global Affairs, 1, http://eng.globalaffairs. ru/number/n_639 (accessed 15 March 2017).

2012. Russia can pivot to the Pacific, too. Carnegie Moscow Center, 7 September. http://www.carnegie.ru/2012/09/07/russia-can-pivot-to-pacific-ttoo/e20 (accessed 15 March 2017). 
2015. Russian foreign policy as exercise in nation building. In Russia's foreign policy: Ideas, domestic politics and external relations, eds. Cadier, D. and Light, M. New York: Palgrave Macmillan.

Tsygankov, A. 2005. Vladimir Putin's vision of Russia as a normal great power. PostSoviet Affairs 21 (2): 13-58, https://doi.org/10.2747/1060-586X.21.2.132.

2009. Russia in the post-Western world: The end of normalization paradigm? Post-Soviet Affairs 25 (4): 347-369, https://doi.org/10.2747/1060-586X.24.4.347. 2010. Russia's foreign policy: Change and continuity in national identity. Lanham, MD: Rowman \& Littlefield Publishers.

Walton, D. 2007. Geopolitics and the great powers in the twenty-first century: Multipolarity and the revolution in strategic perspective. London and New York: Routledge.

Waltz, K. 1979. Theory of international politics. New York: McGraw Hill.

Wishnick, E. 2016. In search of the 'Other' in Asia: Russia-China relations revisited. The Pacific Review 30 (1): 114-132, https://doi.org/10.1080/09512748. 2016.1201129.

Xinhua. 2014. Xi's Sochi visit to deepen Sino-Russian ties. Xinhua Insight, 2 February. http://news.xinhuanet.com/english/indepth/2014-02/02/c1330897282.html (accessed 15 March 2017).

Yu, B. 2007. In search for a normal relationship: China and Russia into the 21st Century. China and Eurasia Forum Quarterly 5 (4): 47-81.

Zhao, H. 2016. Sino-Russian economic cooperation in the Far East and Central Asia since 2012. Eurasia Border Review 6 (1): 103-121, http://doi.org/10.14943/ebr.6.1.103.

Ziegler, C. 2012. Conceptualizing sovereignty in Russian foreign policy: Realist and constructivist perspectives. International Politics 49: 400-417, https://doi. org/10.1057/ip.2012.7. 